January 2004

\title{
Our Right to Work, Our Demand to be Heard: People with \\ Disabilities, the 2004 Election, and Beyond
}

The Honorable Tony Coelho

Follow this and additional works at: https://digitalcommons.nyls.edu/nyls_law_review

Part of the Civil Rights and Discrimination Commons, Disability Law Commons, and the Human Rights Law Commons

\section{Recommended Citation}

The Honorable Tony Coelho, Our Right to Work, Our Demand to be Heard: People with Disabilities, the 2004 Election, and Beyond, 48 N.Y.L. SCH. L. REV. (2003-2004).

This Article is brought to you for free and open access by DigitalCommons@NYLS. It has been accepted for inclusion in NYLS Law Review by an authorized editor of DigitalCommons@NYLS. 


\title{
OUR RIGHT TO WORK, OUR DEMAND TO BE HEARD: PEOPLE WITH DISABILITIES, THE 2004 ELECTION, AND BEYOND
}

\author{
New York Law School \\ October 24, 2003
}

\section{The Honorable Tony Coelho*}

We meet today out of a patriotic sense of national purpose to challenge the country we love to redeem its promise for every American, including the 54 million of our citizens whom we call people with disabilities. ${ }^{1}$

We are a diverse country. All of us pursue our vision of citizenship differently; all of us carry a special definition of the ideal we want our nation to attain. This is what makes our country vital and relevant well into its third century.

I believe America's greatest strength is its capacity for progress and advancement; the belief that prosperity and justice are not meant to be hoarded but shared; that when the American dream is

* Member, U.S. House of Representatives, 1979-1989; Majority Whip, 1987-1989; Chairman, Democratic Congressional Campaign Committee, 1981-1986. Chairman, President's Committee on Employment of People with Disabilities, 1998-2000. Vice Chair, Presidential Task Force on the Employment of Adults with Disabilities, 19982000. Chairman-elect, Board of Directors, Epilepsy Foundation of America, 2003. B.A., Loyola Marymount University, 1964.

I would like to thank David Dreyer for his essential help with this speech. I am also grateful to Alexandra Finucane, Seth Harris, Andrew Imparato, Paul Steven Miller, and Rebecca Ogle for their valuable insights, comments, and friendship. The hard work of Amelia Baker, Amanda Gaynor, and Greg Rutstein transformed this speech into a form appropriate to publication in a law review. This speech would not have been possible without the sponsorship of New York Law School's Labor \& Employment Law Programs and the support of the Epilepsy Foundation of America and many other organizations and individuals in the disabilities community. Nonetheless, all views expressed in this speech are mine.

1. See U.S. Census Bureau Disability Status: 2000 , available at http://www.census. gov/hhes/www/disable/disabstat $2 \mathrm{k} / \mathrm{tablel}$.html (the total number of people with disabilities in the year 2000 was $49,746,248$; excluded from this number are people under the age of five, people in the military, and people who are in institutions). Including categories left out by this data, we estimate the total number of Americans with disabilities to be approximately 54 million. 
available to ever-greater numbers of us, that itself is the well-spring of our national security and prosperity.

For generations of Americans, the right and ability to work at a trade or profession was the key to realizing that dream, and the national prosperity that followed. But, as I learned when my epilepsy was discovered, when legalized bigotry left me unemployed and unemployable, work means much more than financial stability.

Work provides discipline and structure to our lives. It is a source of identity and social acceptance. While love makes relationships and family possible, work makes sustaining life and building a material existence vastly easier. Without work we are doomed to fail. With work, we may still fail, but we at least have the dignity of trying to succeed for ourselves.

That is why I believe the right of Americans with disabilities to work must become an important part of our national debate, as we prepare to choose a president next year.

I have had the privilege of taking part in this national debate for four decades. I have seen remarkable leaders and movements push our nation forward. But during those years, only two men fully tested the power of Presidential leadership to "bend the arc of history toward justice." 2

One was a Democrat, born in poverty, a white man aligned with the Southern establishment, who forced forward the cause of black Americans; the other, a Republican, born to privilege and aligned with business, who embraced the cause of the disabled as his own.

Their gift of leadership was selfless: neither gained political advantage; and neither won another election.

But these men of enduring courage knew our society would be incomplete unless they fought for greater inclusion in our national life. By signing the Civil Rights Act, ${ }^{3}$ the Voting Rights Act, ${ }^{4}$ and

2. Dr. Martin Luther King Jr., Where Do We Go From Here?, in A TEstament of Hope, The Essential Writings and Speeches of Martin Luther King, Jr. 245, 252 (James M. Washington ed., 1986).

3. See Lyndon B. Johnson, Radio and Television Remarks Upon Signing the Civil Rights Bill, in Public Papers of the Presidents of the United States: Lundon B. JohnsON: 1963-4 842 (1965).

4. See Lyndon B. Johnson, Statement of the President Following Passage by the Senate of the Voting Rights Bill, in Public Papers of the Presidents of the United States: LynDON B. JOHNSON: 1965581 (1966). 
the Americans with Disabilities Act, ${ }^{5}$ Lyndon Baines Johnson and George Herbert Walker Bush earned lasting places of greatness in America's history.

The ADA was a landmark piece of legislation that led many of us to think that we would enter a golden age for the disabled community. This legislation was an important achievement for the disabled and began the process of opening the door of respect and full participation to our community. It was opened a crack, but now there are those who want to slam it back shut.

Today, there are ten major party candidates running for President - nine Democrats and President Bush - and all are good people. Many say the right words and offer us the right policies. We've heard disability plans, employment plans, and health plans, and each one might well enable some disabled Americans to live better, more independent lives.

But none of them has dared to take the concerns at the center of our community and place them consistently at the center of their campaigns. None has recognized the importance of work to our agenda commensurate with the needs of our community. None has acted, in the words of Dr. King, as the "drum major for justice" that disabled Americans need our next President to be. ${ }^{6}$

There are 377 days until the 2004 election. It's going to be very close. To win this election - and to govern with greatness - I believe that each candidate running for President should look to our community for the margin of victory for his campaign and moral advantage for his cause.

We have the power to decide the election; if we chose to use it. But I am not sure that we will.

Let's be honest: we're not powerful. We're not registered or rich. We're not really well-organized. Many of us fight important battles for education and health care, but we're not united in our priorities.

5. See George Bush, Statement on Signing the Americans with Disabilities Act of 1990 , in Public Papers of the Presidents of the United States: George Bush, 19901070 (1991).

6. Dr. Martin Luther King, The Drum Major Instinct, in A Testament of Hope, The Essential. Writings and Speeches of Martin Luther King, Jr. 259, 267 (James M. Washington ed., 1986). 
Some of us ask for everything, and that's completely unrealistic. Some of us settle for the empty promise of more federal funds; the empty gestures of White House summits or a presidential advisor; or the empty warmth of rhetoric that too often sounds like pity. And if we settle for those things this year, we'll get nothing, or close to it; and shame on us if we do.

We need a leader who brings his or her passion to our issues. And we need a leader who will really lead - like the first President Bush so honorably did.

But leadership requires a challenge. The disability community clearly has many. But today, I'd like to offer a new challenge - to the candidates who need our votes and to the disability community I love so much: pledge that you will do everything within your power to ensure that this election will emphasize - simply and directly - our right to work.

Our agenda for work is powerful and clear: the Americans with Disabilities Act is under savage attack in the courts, and we must save it. ADA protections for the right to work are being whittled away, and we must restore them.

The federal government's purchasing and hiring power to spur this right to work for the disabled lies dormant, and we must revive it. And the programs that lead to work - programs that educate, train, and address our medical needs - remain under-financed, and we must force Washington to honor these commitments.

Many candidates ask for our support. But we can only support a candidate for President who adopts this agenda for work, and directly embraces our position on five core issues.

First, I believe the disability community should only support candidates who pledge to appoint judges who will respect the ADA as the law of this land.

The ADA is our community's single most powerful guarantor of the right to seek work without fear of discrimination.

Yet, today it is under fire; the greatest threat to the ADA is an organized assault led by ideologues in the Federalist Society and elsewhere, designed to tear down its protections and with them our right to work. 
Once conservatives warned us against judicial activism; now they are the vanguard - twisting the plain language of the statute, ignoring legislative history, reviving long dormant and discredited theories of states' rights, making a mockery of the protections I wrote into this law.

Over the past four years, the Supreme Court has issued a halfdozen decisions that have radically narrowed the scope of the ADA's coverage. But for sheer outrage, let me offer this trilogy of cases: Sutton v. United Airlines, ${ }^{7}$ Albertson's, Inc. v. Kirkingburg, ${ }^{8}$ and Murphy v. United Parcel Service. ${ }^{9}$

The law clearly says that only a person with a physical or mental impairment that substantially limits one or more major life activities has a disability and is covered under the $\mathrm{ADA} .{ }^{10}$ In those three cases, the Court held that whether an impairment substantially limits a worker's activities must be determined by taking into account "corrective measures" taken by the worker."

So, workers with monocular vision whose brains have compensated so that they could functionally see; 12 workers whose high blood pressure is controlled by medication; ${ }^{13}$ and workers who wear corrective lenses to reach $20 / 20$ vision ${ }^{14}$ were no longer substantially limited by their impairments, and their employers were free to discriminate against them.

It didn't matter that every one of those workers was denied a job because they had that very same condition; monocular vision, high blood pressure, myopia. ${ }^{15}$ They have no recourse, because they have effectively treated their disability.

7. 527 U.S. 471 (1999).

8. Id. at 555 .

9. Id. at 516 .

10. See 42 U.S.C. $\$ 12102(2)$ (A) (2003) (defining "disability" as "a physical or mental impairment that substantially limits one or more of the major life activities of [an] individual").

11. See Sutton, 527 U.S. at 481; Albertson's, Inc., 527 U.S. at 565-66; Murphy, 527 U.S. at 571 .

12. See Albertson's, Inc., 527 U.S. at 564.

13. See Murphy, 527 U.S. at 519.

14. See Sutton, 527 U.S. at 481. 476.

15. See Albertson's, Inc., 527 U.S. at 560; Murphy, 527 U.S. at 520; Sutton, 527 U.S. at 
That's like saying it doesn't matter that I have epilepsy - if I take Phenobarbital to control my seizures, and I do - I am not disabled, and am not protected by the ADA.

The Supreme Court wrote me out of my own bill!

Well, excuse me, but I wrote this law. That is not what Congress said. In fact, the House and Senate Committees that passed the ADA wrote in their reports that corrective measures should not - should not - be taken into account when determining whether a worker has a disability. ${ }^{16}$

Thanks to the occluded legal vision of a handful of conservative jurists, it is becoming safe once again to discriminate against disabled Americans seeking jobs. Since these Supreme Court decisions, most lower courts have applied the Court's interpretation to deny ADA coverage to people with disabilities like epilepsy, ${ }^{17}$ multiple sclerosis, ${ }^{18}$ cancer, ${ }^{19}$ bipolar disorder, ${ }^{20}$ and diabetes. ${ }^{21}$

This threat of judicial activism can only grow. We got a taste of that this year when President Bush nominated Jeffrey Sutton, a known opponent of the ADA, to the U.S. Court of Appeals. ${ }^{22}$

As a lawyer, Sutton branded core protections passed by Congress for the disabled as improper and unneeded. ${ }^{23}$ He persuaded the Supreme Court to prohibit state employees with disabilities

16. See H.R. Rep. No. 101-485 (III) at 28-29 (1990) ("The impairment should be assessed without considering whether mitigating measures, such as auxiliary aids or reasonable accommodations, would result in a less-than-substantial limitation. For example, a person with epilepsy, an impairment which substantially limits a major life activity, is covered under this test, even if the effects of the impairment which substantially limits a major life activity, is also covered, even if the hearing loss is corrected by the use of a hearing aid."); S. Rep. No. 101-116, at 23 (1989) ("Another important goal of the third prong of the definition is to ensure that persons with medical conditions that are under control, and that therefore do not currently limit major life activities, are not discriminated against on the basis of their medical conditions.").

17. See Brunke v. Goodyear Tire and Rubber Co., 344 F.3d 819 (8th Cir. 2003).

18. See Croy v. Cobe Laboratories, Inc., 345 F.3d 1119 (10th Cir. 2003).

19. See Liljedahl v. Ryder Student Transportation Svcs., Inc., 341 F.3d 836 (8th Cir. 2003).

20. See Hoeller v. Eaton Corp., 149 F.3d 621 (7th Cir. 1998).

21. See Fraser v. Goodale, 342 F.3d 1032 (9th Cir. 2003).

22. See Neil A. Lewis, Senate Approves a Nominee; Filibuster Is Set for Another, N.Y. Times, April 30, 2003, at A22. By a 52 to 41 vote, the Senate narrowly confirmed President Bush's nomination of Jeffrey Sutton to a seat on the United States Court of Appeals for the Sixth Circuit.

23. See Brief for Petitioners, Board of Trustees of the Univ. of Alabama v. Garrett, 531 U.S. 356 (2001) (No. 99-1240). 
from suing their employers. ${ }^{24} \mathrm{He}$ argued that disabled people should be segregated in institutions. ${ }^{25}$ Sutton is a disaster for our community, but President Bush nominated him and the United States Senate let him through. ${ }^{26}$

And Judge Sutton is only the beginning. There are 16 vacancies in the Circuit Courts today, and twenty-five more in the trial courts. The next President could nominate three or more justices to a Supreme Court that has ADA cases on the docket this fall and can expect more tests in the near future.

If the next President packs our courts with jurists who reverse the plain meaning of the law - as this Supreme Court has ${ }^{27}$ — or who batter the ADA with strained versions of states' rights reasoning - as this Supreme Court has ${ }^{28}$ — or who deny workers meaningful accommodations - as this Supreme Court has ${ }^{29}$ - the ADA will be no more.

Any candidate asking for our support must answer this question: will you work to appoint judges who understand the importance of broadening, not narrowing, access for the disabled to work?

Second, to reverse the damage caused by these decisions, we should only support those candidates who pledge to restore the ADA to its original goals and purposes.

We must restore the coverage of people with disabilities under the ADA, undo the restrictions placed by the Supreme Court on the classes of people protected by the law, and reopen the remedies available to those who successfully prove $\mathrm{ADA}$ violations. We must restore the obligation of employers to comply with the requirement for meaningful accommodations.

24. See id. at $3-4$.

25. See Brief for Petitioners at 13-15, Olmstead v. L.C., 527 U.S. 581 (1999) (No. 98-536).

26. See Lewis, supra note 22.

27. See, e.g., Sutton v. United Airlines, 527 U.S. 471 (1999); Albertson's, Inc. v. Kirkingburg, 527 U.S. 555 (1999); Murphy v. United Parcel Service, 527 U.S. 516 (1999).

28. See Board of Trustees of the Univ. of Alabama v. Garrett, 531 U.S. 356 (2001).

29. See U.S. Airways v. Barnett, 535 U.S. 391 (2002). 
And we must reverse the Court's decisions that permit people with diabetes, heart conditions, cancer and epilepsy to lose their legal rights, because medications make them "too functional" to be protected under the law.

The time is right for a candidate for President to propose an ADA Restoration Act, because we want our right to work restored.

Third, I believe we should only support those candidates who pledge to use the federal government's massive purchasing power to increase the employment of people with disabilities in the private sector.

Seventy-percent of blind and disabled Americans don't have jobs. ${ }^{30}$ The federal government is the world's largest buyer of goods; ${ }^{31}$ and I say it's time to put its purchasing power behind the economic empowerment of people with disabilities. We can do that in three simple ways.

First, the Executive Orders that prevent federal contractors from discriminating against racial minorities and women should also prevent discrimination against people with disabilities. ${ }^{32}$ This means putting teeth into affirmative action for people with disabilities. ${ }^{33}$ The Supreme Court recently ruled that diversity in law school admissions is permissible, ${ }^{34}$ and I believe that equal value should be placed on diversity in the workplace. Federal contractors

30. See Seth D. Harris, Introduction: Understanding the Context for the "Coelho Challenge," 48 N.Y. L. Sch. L. Rev. 711, 714 n.16 and accompanying text (2004).

31. U.S. Small Bus. Admin., Doing Business with the Federal Government (July 2001), at http://www.sba.gov/opc/pubs/fs0009.html (last modified July 3, 2001).

32. Two executive orders protect against discrimination on the basis of race, sex, and other protected classifications, but do not protect workers with disabilities. See Exec. Order No. 11246, 3 C.F.R. 339, 340 (1964-1965), reprinted as amended in 42 U.S.C. $\$ 2000$ e (1994); Exec. Order No. 11375, 3 C.F.R. $\$ 684$ (1967) (added "sex" to Exec. Order No. 11246's affirmative action and anti-discrimination commands).

33. The Rehabilitation Act of 1973, Pub. L. No. 93-112, 87 Stat. 357 (codified at 29 U.S.C. $\$ \S 701-18$ ), imposed limited affirmative action requirements on federal contractors. See also 29 U.S.C. $\$ 791$ (b) (2003) (requiring the annual submission to the Interagency Committee on Employees who are Individuals with Disabilities, an affirmative action plan by each executive branch department, agency and instrumentality, for the hiring, placement, and advancement of individuals with disabilities in such department, agency, or instrumentality).

34. See Grutter v. Bollinger, 539 U.S. 306 (2003). 
employ $25 \%$ of all Americans ${ }^{35}$ - which makes these employers a powerful force for getting more disabled workers into jobs.

Most important, this proposal does not require an Act of Congress; it takes only strong presidential leadership and the stroke of his pen.

Second, the federal government can reserve a portion of its contracting for businesses owned by the disabled. The Small Business Administration's 8(a) program does this already, for small firms owned by women and the socially disadvantaged. ${ }^{36}$ Six thousand American companies already enjoy this "foothold" in contracting with the federal government. ${ }^{37}$

During 1999 alone, the last year with published figures, these small businesses got contracts with federal agencies amounting to more than $\$ 6$ billion - helping to sustain nearly 200,000 jobs. ${ }^{38}$

But business-owners with disabilities were not among those firms, and that must be changed. ${ }^{39}$ One important strategy for increasing the employment of people with disabilities is to expand the number of entrepreneurs with disabilities. This proposal will help accomplish that goal.

Third, the Javits-Wagner-O'Day Program creates jobs and provides training for disabled workers by requiring government agencies to purchase selected products and services from nonprofit agencies employing such individuals. ${ }^{40}$

35. Report on Performance and Accountability, Outcome Goal 3.2: Foster Equal Opportunity Workplaces, U.S. Dep't of Lab. Ann. Rep. 107 (2002), available at http://www.dol. gov/_sec/media/reports/annual2002/Goal3_2.pdf.

36. 13 C.F.R $\$ 124.103$ (b) (2001).

37. See Gail Repsher Emery, Special Report on the 8(a) Program: Plotting Their Exit Strategies, Wash. Tech., September 23, 2002, available at http://www.washingtontechno logy.com/news/17_13/federal/18981-1.html.

38. U.S. Small Bus. Admin., A Report to Congress on Minority Small Business and Capital Ownership Development for Fiscal Year 1999, at 5, available at http:// www.sba.gov/8abd/annualreport99.pdf.

39. 13 C.F.R. $\$ 124.103$ (b)-(d) (1998).

40. 41 U.S.C. $\$ 47$ (2000). See generally Allan V. Burman, Tapping a Unique Labor Pool, Gov'r Exec. MAG., Mar. 29, 2000, available at http://www.govexec.com/procure/ articles/0400market2.htm (discussing the administration and implementation of the Javits-Wagner-O’Day Program). 
Under this law, however, only those employers who can prove that $75 \%$ of their labor hours are performed by people with disabilities are eligible. ${ }^{41}$

An employer doing a good job hiring people with disabilities can still not qualify, unless he turns his workplace into a disabilities ghetto - and that's wrong. We need to lower this threshold, so that more employers who hire the disabled will benefit from federal government contracts without creating segregated workplaces.

I believe that the late Senator Robert Wagner, who got his law degree from this great institution, would proudly endorse the change I recommend today. ${ }^{42}$

Fourth, the disability community should only support those candidates who will dramatically increase the number of people with disabilities employed by the federal government.

The federal government should be leading the private sector by example, but it is not. Let me give you just one example.

In July 2000, then-President Clinton signed an Executive Order that required the executive branch to hire 100,000 people with disabilities before the ADA's fifteenth anniversary in the year $2005 .{ }^{43}$

President George W. Bush neither repealed nor endorsed this Executive Order, but it is still in force. According to the latest data, the executive branch under this president only hired 2,800 disabled workers in the following two years. ${ }^{44}$ Employment in the Executive Branch is actually rising, but the percentage of disabled government workers is shrinking. ${ }^{45}$ The number of people with disabilities employed by the federal government is lower now than it was in 1994,1996 , and $1998^{46}$ and, with outsourcing, it is likely to shrink further still.

41. See 41 USC $\$ 48 b(3)$ (c) (2003).

42. Robert Wagner received his law degree from New York Law School in 1902. See J. Joseph Huthmacher, Senator Robert F. Wagner and the Rise of Urban LiberALISM 15 (1968).

43. See Exec. Order No. 13163, 65 Fed. Reg. 46563 (July 28, 2000).

44. See U.S. Office of Pers. Mgmt., Federal Civilian Workforce Statistics: The FACT Book 2002 Edition 42-43 (June 2002), available at http://www.opm.gov/feddata/ 02factbk.pdf (last visited Nov. 25, 2003).

45. Id.

46. Id. 
To comply with the Executive Order, the government would have to hire 2,800 new disabled workers every month of the next President's term to meet the goal of 100,000 by 2009 ; that's four years late!

We need a President who will take the hiring of disabled federal workers seriously, and reach these targets on a timetable against which they can be held accountable, because disabled workers desperately need those jobs.

Fifth, the disability community should only support those candidates who will change the federal policies that stop people with disabilities from working.

The federal government is better at paying disabled people to stay home than it is at granting the assistance they need so they can afford to work.

People with disabilities in the SSDI system who earn more than $\$ 800$ a month at their jobs risk losing their benefits entirely. ${ }^{47}$ Leaving the disability rolls and taking a job is a real roll of the dice, even with the Ticket to Work Act. ${ }^{48}$ Businesses are cutting back on health care, or terminating their plans altogether, but rarely offer the scope and scale of benefits that disabled people truly need. In effect, the health care system in our country teams with the SSDI system to trap us at home.

And even if we forsake work, Medicare and Medicaid programs are being cut in Washington and at the state level because of tax cuts previously awarded by President George W. Bush to people of great wealth.

The next President must reform the Social Security disability system to guarantee the right to work while assuring that people

47. See Substantial Gainful Activity Amounts, 65 Fed. Reg. 82905 (Dec. 29, 2000) (providing the method used by the Social Security Administration to calculate the wage measure of "substantial gainful activity"); see also Substantial Gainful Activity Amounts, http://www.ssa.gov/OACT/COLA/SGA.html.

48. See Ticket to Work and Work Incentives Act, 42 U.S.C. $\$ 1320 \mathrm{~b}-19$ (2003) (allowing states to provide social securities disabilities insurance recipients to opt into a program that assures health insurance for a period after leaving the disabilities rolls along with funding for services to help people with disabilities find employment, but without guarantees as to the availability of appropriate services, employment opportunities, or long-term health insurance). 
who cannot work will get the income support and health care they need.

We must have a President who will respect and honor our desire to work.

My passion for expanding job opportunities for disabled Americans is rooted in my life - in the pain and personal failure I felt when I was prevented from working - and in the confidence and ability to contribute I rediscovered when I was finally able to find work once again.

When I graduated college, I had high hopes for the future. I had a fairly successful academic career. I had been voted "outstanding senior." And I had left my girlfriend to prepare for life with the Jesuits as a priest.

Before entering the Seminary, I had to take a physical exam. I saw the doctor on June 15th, 1964, my birthday. When it was over, the doctor said he had good news and bad news. The examination revealed something that would keep me from going to Vietnam. The bad news was that I had epilepsy. Suddenly, my future was in jeopardy; and, in very short order, my life was upside-down.

Because Catholic canon law then prevented epileptics from becoming priests, the Church took away my robes. ${ }^{49}$ The State of California took away my driver's license. ${ }^{50}$ The insurance company took away my coverage. And employers took away my power to earn a living with the words: "Epileptics need not apply."

After so many defeats, I lost hope. Many days I was drunk by noon; many nights I slept outside; many mornings I would wake up and not know where I was or how I had gotten there. I was living in a tunnel of hopelessness and the light was growing dimmer every day. I became suicidal. I didn't know what to do or where to turn.

I was lost until I learned I could channel my passion for public service into the political process.

49. See 1917 CoDe c.984, $\$ 3$ ("Qui epileptici vel amentes vel a daemone possessi sunt vel fuerent," which translates to "those with epilepsy and those possessed by the devil could not be considered for ordination").

50. Pursuant to CAL. VEH. CoDE. $\$ 12806$ (c) (1964), the state was permitted to refuse to issue or renew an individual's driver's license if he or she "has a disorder characterized by lapses of consciousness ... or who has any physical or mental disability, disease, or disorder which could affect the safe operation of a motor vehicle. ..." 
When I found Congress, I found myself, and with the help of a great employer, Congressman Bernie Sisk - with the support of great friends and a loving wife $-I$ have enjoyed a long career on Capitol Hill, in business, and beyond.

In the Congress, I had great opportunities - to work for social change, to serve the interests of my district, and to broaden the base of my Party. Most importantly, I got to write the ADA - and see it signed into law - and to begin returning to our community the opportunities granted to me.

The ADA has opened many doors for the disability community. But to me, the most important door is the one that leads to America's workplaces. Because I know - coming from where I started and arriving where I am now - that everything else we want for our lives depends on gaining greater work opportunities for the disabled men and women of our country.

Some will tell us now is not the time. The security challenge is too great. The economy is too weak. Our demands, however just, must wait until the next legislative session, the next election, and ultimately, another day.

That is nonsense.

If the candidates say they can only handle a desk with in-boxes labeled "economics" and "foreign policy," they'd better get a bigger desk, or we must demand and elect a better President.

This election has to be about our right to succeed. Your right to prosper and to pay taxes. Your right to lead independent lives. Your right to provide for our families. Your right to advance. Your right to the American dream. These are our goals - and we must make ourselves heard.

If we force these candidates to speak, clearly and directly, about how they will take down our barriers to work, we will not simply be heard, we will be respected. And if we force a change in this campaign's debate, we will forever change national policy toward the disabled, and we will permanently change our lives and our nation for the generations that follow. 
